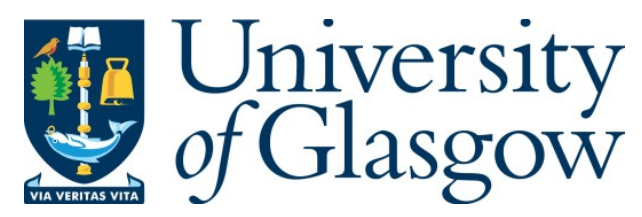

Hill, M., Lockyer, A., Head, G., and McDonald, C. A. (2017) Voting at 16 - lessons for the future from the Scottish Referendum. Scottish Affairs, 26(1), pp. 48-68.

There may be differences between this version and the published version. You are advised to consult the publisher's version if you wish to cite from it.

http://eprints.gla.ac.uk/135946/

Deposited on: 31 January 2017

Enlighten - Research publications by members of the University of Glasgow http://eprints.gla.ac.uk 


\section{Voting at 16 - lessons for the future from the Scottish Referendum}

Malcolm Hill, Andrew Lockyer, George Head, Craig MacDonald

Address: School of Applied Social Studies, University of Strathclyde, Lord Hope

Building, 141 St James Road, Glasgow G4 0LT

Malcolm.Hill@strath.ac.uk

\section{Biographical notes}

Malcolm Hill is Emeritus Professor at the University of Strathclyde and was for a number of years Director of the Glasgow Centre for the Child \& Society. Andrew Lockyer has taught politics for many years at Glasgow University and is currently the Stevenson Professor of Citizenship. Dr George Head is recently retired, after a long period in the Faculty of Education, University of Glasgow. Craig McDonald has carried out several pieces of research at the Universities of Glasgow and Strathclyde.

words 


\title{
Voting at 16 - lessons for the future from the Scottish Referendum
}

\begin{abstract}
The 2014 Referendum on Scottish independence raised many issues about the future of Scotland. It also produced an innovation as regards the electoral process by making 16 years the minimum age of participation. This article examines issues surrounding the voting age and draws on a schools-based study, which shed light on teacher and pupil opinion about this lower than usual threshold for voting. It is also concerned with how schools cover the teaching of politics and prepared students for the Referendum debate within a context of expected neutrality on a highly divisive matter. Some implications of extending the lower voting age for future elections are discussed.
\end{abstract}

Keywords Voting age; franchise; Referendum; schools; political literacy; transitions to adulthood

\section{Introduction}

The 2014 Referendum on Scottish independence was of course a critical event concerning the future of Scotland.. This article is not concerned per se with the central debate on independence versus staying in the union, but is about another feature of the Referendum: namely that for the first time in a major vote in Britain, young people aged 16 and 17 were able to take part. Subsequently the franchise for Scottish Parliamentary elections was also extended to those aged 16 to 18 . The current Westminster Government is disinclined to lower the voting age of 18 for UK elections. It also rejected a House of Lords amendment to the EU Referendum Bill that would have enabled 16- and 17-year olds to participate in the EU Referendum.

At present few are advocating that the franchise should be opened to young children, but a number of individuals and organisations are lobbying for 16 to be the standard voting age across the UK (BYC 2015; House of Commons 2015). This article reviews arguments, evidence and attitudes about this suggested lower age threshold. In addition to reviewing relevant literature, we draw on our study carried out in Scottish schools in the lead up to the 2014 Referendum.

\section{Minimum ages of entitlement in general}

The minimum voting age is one of a considerable number of upper or lower age limits enshrined in law that affect the freedoms and actions of children. These mark the legal boundary between childhood and adulthood. They relate to matters such as criminal responsibility, consent to sex, marriage, engagement in full time work, ability to drive a car on public roads and joining the armed forces. Nearly all countries have such age limits, but they can vary considerably in the age used. Moreover many countries change the age limit from time to time. The lack of consistency in age limits reflects the fact that the transition from childhood to adulthood is neither clear nor fixed, as recognised by the intermediate phase of adolescence or youth (Furlong and Cartmel 
2006; Fass 2014). One consequence of the present age limits is that 16-17 year olds may be married, pay taxes and/or fight for their country, yet have no democratic power to affect national family, fiscal and military policies.

Defenders of age limits argue that they are 'in their (children's) best interests' (Purdy 1992); they are necessary to protect children from harm or exploitation, and/or reflect a deficiency in children's abilities. Although age is not an exact marker of competence, it can be seen as a valuable proxy (Chan and Clayton 2006). Some people accept that age limits may be necessary, but criticise their arbitrary nature and want some changed. Certain children's rights activists have argued that such limits should be abolished (Holt 1971; Franklin 1986). They suggest that sufficient protection for children or society arises from inherent restraints in the capacities and motivations of children, particularly younger ones.

The social studies of childhood has in recent decades questioned or rejected the 'representations' of young people as incompetent that are seen to underpin age limits (Prout and James 1998; Lansdown 2011; Qvortrup et al 2011). From this perspective, legal decisions to exclude young people from certain adult entitlements as citizens, such as voting, are seen to reflect adult's power and children's lack of power (Qvortrup et al 1994; Jencks 1996; Liebel 2012). This perspective is part of wider movements in practice as well as academe that suggest children and young people's agency and abilities have been undervalued. Similarly their views have been ignored or marginalised (Liebel 2012). The exclusion of children and young people from voting is from this point of view part and parcel of a more general exclusion from adult activities and from influential decisions (Harris 1982). Wyness (2012) notes that 'children have the same problems in claiming political status as they do any rights to self-determination' (p. 240).

\section{The minimum voting age}

All democracies exclude part of their population from the right to vote. It was not until the $19^{\text {th }}$ century that full universal suffrage for adult men was achieved in the UK, while adult women were not entitled to vote until the $20^{\text {th }}$ Century ${ }^{1}$. Previous restrictions limiting the franchise were gradually challenged and then over come as they were increasingly regarded as undemocratic and unjust. Now children and young people are the only sizeable section of the citizen population excluded from voting.

For much of the twentieth century, the minimum voting age in the UK (and many other countries) was 21 , though originally higher for women when female suffrage was first achieved. After 1945 a gradual worldwide trend emerged to reduce the voting threshold to 18, which happened in the UK in 1970. During the 1990s, some states in federal countries like Germany and the USA lowered the relevant age further to 16 . Brazil had already legislated for that age to apply in national elections in 1989. In 2004, only 9 countries in the UN had an age of majority below 18 and not all of these were liberal democracies (Electoral Commission 2004). In 2007 Austria became the first EU state to adopt a voting age of 16+ for most purposes. Closer to home voting at 16 was adopted as the norm in three British Crown Dependencies - The Isle of Man, Jersey and Guernsey between 2006 and 2008. Currently the age of 18 still

1 There remain a few exceptions to adult voting rights in the UK, such as people in prison. 
remains by far the most common age worldwide for voting in national elections.

Two main factors have influenced demands for a reduction in the age of majority first that it is intrinsically justified by young people's abilities and entitlement and second that it would help with perceived public disengagement from politics. In 1999, the Westminster Parliament considered this issue, but there was little support for making a change (House of Commons 2015). Not long afterwards, the UK Electoral Commission (2004) reviewed the arguments for and against in a response to growing calls to lower the minimum age for voting. Its conclusion was in favour of the status quo. This was mainly based on opinion poll evidence that most adults preferred 18 and that young people were themselves divided. The Commission noted that some people under 18 would be ready to exercise the right to vote, but 'many others do not appear ready' (p. 4). However the Commission stated that circumstances could change if citizenship education improved and a wide debate led to changes in attitude. Thus a lower age was regarded as currently inappropriate, but not necessarily for ever. This viewpoint was accepted by the UK Government. Grover (2011) has suggested that Westminster politicians were concerned about the unpredictability of young people's voting behaviour. The Scottish Referendum was the first time that age 16 was used in a major public vote within the UK (Tierney 2014).

One of the main reasons why children and young people aged under 18 have not been allowed to vote is that they are perceived as lacking the intellectual capacities or maturity to make such an important decision (Blackburn 1993). Alongside this essentialist view about young people is a more conditional argument that, currently at least, they lack adequate awareness and exposure to political debates (Mycock 2014). The latter contention implies that young people could be adequately prepared if citizenship education was more extensive and effective. They have the capacity or potential ability required to vote but not yet the actual competence (Cowden 2010).

Support for this perceived lack of ability can be derived from psychological theory and research about limitations in teenagers' cognitive competence. Although there are wide individual variations, most young people in their teens are still in the process of developing mental skills seen to be required of adult responsibilities, such as reasoning, abstract and holistic thinking, and seeing the world from viewpoints other than one's own. Full systemic thinking and consideration of multiple interests may not emerge until 19 or later (Furnham and Stacey 1991; Lehalle 2006). The lability of the teen years has also been seen as affecting rational judgement. Furthermore, surveys have shown that young people lack knowledge or are uncertain about key aspects of national and local political life (Furnham and Gunter 1989). Many young people have stated they do not know enough to make informed political choices (Fahmi 2006).

On the other hand, it has also been suggested that psychological notions of adolescence have been distorted and fuelled public perceptions that young people are problematic and unreliable as potential voters (Griffin 2004). Moreover, understanding of political issues and processes and motivation to participate are not necessarily fixed, but can be affected by education (Crick and Lockyer 2010). The argument for excluding children from voting based on children's lack of interest in politics was also used to justify denying suffrage to women (Lister 2003). 
For many children's and youth rights advocates, 16 and 17 year olds are sufficiently capable to form judgements. Children aged well below 16 have been able to participate effectively in children's and youth parliaments, though access to these has been uneven (Turkie 2010; Wyness 2012). Moreover, arguments for a lower voting age have been developed from principles underlying both human and children's rights. Grover (2011) states that suffrage is a universal human right and so should not be denied children on the grounds of age or incompetence. Similarly Cowden (2010) supports the view that a child's entitlement to vote does not depend on full awareness of the issues: it is sufficient to understand what an election is about and be able to complain about not being allowed to participate. The children's rights and participation literature also emphasises that children and young people under the age of 18 (the usual limit recognised under the UNCRC) are entitled to participate in public decision-making that affects them.

Related to the contentions that some or many 16 year olds lack the intellectual or emotional maturity to make political decisions is the slippery slope argument. If the small difference in competence between 18 year old ands and 16 year olds is insufficient to justify excluding the latter, then the same argument can be applied 'repeatedly until we have enfranchised six-year olds, which would be absurd' (Chan and Clayton p. 540). It might be countered that if this idea is truly absurd then no government would allow the voting age to 'slip' that far.

Some people argue against the lowering of the voting age on the basis not of (in)competence but of the wish to protect children from the responsibility and potential stress involved. This is part of a wider wish to leave children free of the 'burdens' of adulthood for as long as possible.

\section{The study of schools in relation to the 2014 referendum}

Our research was carried out in 2014 in the period leading up to the Scottish Referendum to examine schools' approaches to preparing young people for the vote within the wider context of their arrangements for citizenship education ${ }^{2}$. This was a unique opportunity to study how schools handled the challenge of a highly contested political issue. It enabled us to examine attitudes to the fact that older school pupils were newly enfranchised and to explore young people's preparedness to take part in this special election, in terms of adequacy of information, interest and reasoning, as perceived by pupils and by teachers. In view of sensitivities about neutrality, schools were promised that questions would not be asked about pupils' or teachers' on the desirability or not of independence. Also no comparisons were to be made of different schools and participating authorities.

The study comprised questionnaire surveys. Limited resources for the research meant that it was not possible to carry out interviews or group discussions, as would have been desirable to obtain greater depth. The questionnaires were devised with a mix of fixed choice and open-ended questions. Questions covered four main areas:

1. Approaches to citizenship education

2. Attitudes to voting at 16

\footnotetext{
${ }^{2}$ For full details see www.gla.ac.uk/media/media_404843_enpdf
} 
3. Teaching about politics and the referendum

4 How did teaching on the Referendum compare with teaching on other contentious topics?

This article focuses on topic 2 and 3. The findings about citizenship education and the teaching of contentious issues more broadly will be discussed in a separate paper.

The survey took place in March-August, 2014. 20 state secondary schools and one independent school took part in the study. They were located within two local authority areas in the West of Scotland. A contact teacher in each school was asked to distribute questionnaires to colleagues across a range of subject areas and to students in S5 and S6 classes, who would be either old enough to vote in the Referendum or close to the minimum age of eligibility.

511 questionnaires were received from students in target classes attending 10 schools in each of the two local authority areas and from one senior class in the independent school. Almost two thirds (63\%) were aged 16 or over at the time of completing the questionnaire. Most of the remainder were 15. We did not ask for precise birth dates, so an unknown number of these would have birthdays before the date of the referendum and therefore become eligible to vote.

The sampling of teachers was purposive to gain a spread of subject areas and sufficient numbers without imposing a heavy workload on schools. Completed questionnaires were received from 84 teachers, all in the public sector. A wide selection of subject areas was included, though the largest numbers of questionnaires (more than 10\% each) were returned by people teaching modern studies, English, geography and mathematics.

The quantitative data was analysed with SPSS. Qualitative responses to open ended questions were sorted into categories. Individual quotes in this paper have been selected to accord with the frequency of themes across the two samples.

After the survey results had been analysed, the results were discussed with some staff and students from participating schools at two events. A few comments that were made at these events which seemed to have widespread support will also be referred to in this article. It should be borne in mind, though, that the limited number of students at these events were not a cross-section as in the survey, but those with a particular interest in political issues. The staff consulted were all modern studies teachers.

\section{Pupils' and teacher's views about voting age}

In our study, the majority of young people who took part in the survey supported lowering the voting age. More than half were in favour of retaining the age of 16 for all future elections (57\%), though just over one third wished to revert to 18 as in other recent elections (36\%). A few wanted a different age, no age limit at all, or were undecided. Views about this did not vary significantly with the young person's own age at the time of the survey.

Comments made to elaborate on these opinions illustrated the range of views. Here 
are examples from those favouring a change to 16 or no age threshold:

'It's our future and we are as mature as eighteen year-olds'

'Age should not be the deciding factor on whether or not you can vote',

A small number preferred a younger age than 16. In one person's eyes, it was arbitrary and unfair to be considered less able than classmates on the basis of a small age difference:

'Age shouldn't be the deciding factor on whether you can vote, it needs to be around a certain age, but being a couple of months off being allowed to vote I feel that I am as capable of making a decision as anybody else'

A few of the comments reflect the minority view that an older age is appropriate:

'The voting age should be raised'

'Don't think that sixteen year-olds are mature enough to vote'.

By contrast, the opinion among the cohort of teachers in the survey was by a majority against granting the franchise at 16. 37 of our sample were against lowering the voting age (44\%), but almost as many were in favour $33(39 \%)$. Significantly quite a high proportion of teachers were ambivalent, with 14 (17\%) saying they were undecided.

Although our sample was not very large, it did reveal a substantial difference in viewpoint depending on teacher's main subject area. For example among modern studies teachers, 10 out of $12(80 \%)$ were in favour of voting at 16 . By contrast those teaching languages, sciences or maths were mostly against. Teachers of social subjects other than modern studies were almost evenly divided, but slightly more than half were against. It seems that teachers whose work is least likely to deal with social and political subjects are most inclined to view pupils as ill prepared to vote at 16 , while those who engage with their students frequently about social issues are more inclined to respect their competence to vote.

Our survey asked young people if they were eligible to vote in the Referendum and on the whole their responses tallied well with their ages. However seven of those aged over 16 said they were not eligible and some others admitted to not knowing. 65 who were 15 at the time of the survey stated they would be able to vote. Some of the 15 year olds who claimed to be eligible would pass their $16^{\text {th }}$ birthday in the few months between the survey and the Referendum date, while younger ones were under a misapprehension about eligibility. On the whole, though, it seemed that the publicity and information about the lower age of voting for this particular event had been broadly successful, though with a small number of exceptions.

In the study we wished to asses not only young people's willingness to vote but also how prepared they felt. We asked how well informed pupils felt they were on Referendum issues. Aboutfour in ten thought they were fully informed and almost the same proportion felt only partly informed. This left about one in five saying that 
they were not informed at all ${ }^{3}$. A significant proportion of these student (7\% of the total surveyed) were eligible to vote but indicated that they were ill-prepared to do so. Unfortunately we are not able to compare this with the feeling of being informed among the adult population at large.

\section{Pupils' views on the teaching of politics and the Referendum in School}

Schools had a role in preparing young people for the Referendum, i.e. increasing their competence. As well as focusing on the Referendum debate as it impacted on the experience of pupils and teachers, we sought to view this in the wider context of the teaching of politics in schools.

For some time now, it has been government policy at UK and Scottish levels of government to promote citizenship education. This is meant to embrace not simply the acquisition of knowledge of political institutions and processes, but also the knowledge and skills to participate in democratic and broader civic responsibilities (Crick, 1988; Lockyer 2010). The Electoral Commission (2004) highlighted the importance of improved preparation in schools before voting below 18 should be reconsidered. In Scotland, citizenship education did not become a compulsory part of a National Curriculum and taught as a separate examinable subject as in England, but is supported by the Curriculum for Excellence. The aspiration is to create a capacity for 'responsible citizenship,' including the 'skills, aptitudes and knowledge' associated with political literacy, be embedded across the curriculum. (Education Scotland 2013)

It is usual to recognise three elements citizenship education - social and moral responsibility, community involvement and political literacy. The third of these entails encouragement of learners to develop their own reasoning and make up their own minds by engaging with political and other controversial issues. It has been recognised by educationalists as likely to be most challenging for schools (Munn 2010).

The pupils' questionnaire asked how often did they 'discuss or debate politics or political issues' in school. The results (Table 1) suggest a very wide variation in the amount of politics or discussion on political issues was experienced across the schools in the survey, with one quarter reporting that these were never dealt with.

Table 1 - Frequency of coverage of political issues in $\operatorname{school}(N=516)$

\begin{tabular}{|l|l|l|}
\hline At least once a week & 180 & $35 \%$ \\
\hline A few times each term & 202 & $39 \%$ \\
\hline Not at all & 134 & $26 \%$ \\
\hline
\end{tabular}

Pupils stated that politics was usually dealt with in more than one class, though certain subjects were named much more often than others. By far the most often

\footnotetext{
${ }^{3}$ As the survey occurred 1-6 months before the vote, young people's knowledge probably increased by the Referendum itself. 
mentioned was Modern Studies (136). English (19), History (14) and PSE (11) were the next most common. Small numbers of pupils mentioned subjects with little direct connection with politics, such as Graphics, Music and Science subjects.

About three fifths of the sample of young people were satisfied with the level of attention given to political issues at their school. Nearly two fifths wanted more frequent coverage and only a few thought that the current frequency was excessive. A number of comments were made that showed a strong interest in more extensive and in-depth teaching:

'Teaching of political issues should be increased dramatically'

'The school don't help us to look deep into politics'.

'Politics should be discussed in other subjects, not just modern studies'.

Such views echo the conclusion of representative studies of Scottish young people carried out in 2013 and 2014 most young people do have some interest in politics and a significant minority are very interested (Eichorn 2014a). Taken together, these findings challenge a common adult assertion that many young people are not interested in politics or voting. However the claim that young people tend to show greater commitment to specific issues than more general political matters (Wyness 2012) may well be illustrated by their strong interest in the Referendum. By contrast the Scottish Health Board elections of 2010 had a low turnout of 16 and 17-year olds in (Stewart et al 2014), which suggests that it is important the issues raised by an election must appear relevant and have effective publicity if young people are to engage.

Pupil respondents were asked to state what were the political issues most commonly dealt with in class. The two interlinked topics of independence (114) and the Referendum (84) were easily the most common. Doubtless these responses were affected by the immediate topicality of the Referendum at the time of the research. Even so, only two in five said that they had discussed the subject a lot (Table 2).

Table 2 - Frequency of coverage of the Referendum in school $(N=504)$

\begin{tabular}{|l|c|l|}
\hline A lot & 197 & $39 \%$ \\
\hline A small amount & 237 & $47 \%$ \\
\hline Not at all & 70 & $14 \%$ \\
\hline
\end{tabular}

The majority of our sample said they were satisfied with the amount of time devoted at school to the Referendum. One quarter would have liked more, for example:

'I learn a lot about politics in my school. I think people should be more informed on what a referendum is'.

'We should be taught more about the referendum'

Those wanting more on the Referendum included a disproportionate number of girls 
(102 females compared with 60 males $^{4}$ ). Nearly $10 \%$ of the pupils responded that too much attention had been given to the Referendum. A few voiced negative comments based on indifference or concerns about being influenced inappropriately:

\section{'Politics doesn't interest me' \\ 'People try to tell me why to change my mind and it usually turns into an argument'}

The great majority said they had enjoyed the discussions about the Referendum either a lot or a little (405, nearly $85 \%)$. Among the more than $10 \%$ of the sample (61) who had experienced discussions and found them not enjoyable, the most common reasons ${ }^{5}$ given were boredom or little interest in the subject (25). Two referred to having too much work, which suggested they saw the topic as unimportant compared with other parts of the curriculum. A small number referred to superficiality, i.e. not enough detail or too few facts (6). Only a few (3) explained that they did not understand the issues. Two individuals cited bias as a reason for their dissatisfaction. Interestingly, by contrast several individuals stated that teachers should be allowed to express their opinions. In other words, it would not matter if teachers took sides.

Young people in the survey were asked to state what schools could have done additionally to help them prepare better for the Referendum. Nearly half did not answer. Among the suggestions from others, the most common by far were for more discussion and more direct teaching and presentations. Overall, it seems schools differed widely in their attention to political issues in general and the Referendum in particular, and that there was considerable student support for greater coverage.

\section{Teachers' views on the teaching of political issues and the Referendum in School.}

In order to assess what degree of importance teachers attached to the school's part in equipping young people to vote responsibly, they were asked to rank the three elements of citizenship education: social and moral responsibility, community involvement and political literacy in order of importance 'for society' and 'for schools'. Moral and social responsibility was ranked most important by 8 in 10 teachers; 'community involvement' was of second importance to most teachers, and for most political literacy was of least importance. Only one in ten viewed it to be of first importance and these were mostly teachers of modern studies.

Teachers were also asked how well they thought 'we as a society prepares pupils to engage with democracy'. Only a third thought 'very well' (6\%) or 'fairly well' (27\%); a third thought 'adequately' (33\%) and the same proportion (33\%) thought 'inadequately.' Almost all of the few who thought that political literacy was important for schools to teach also believed pupils to be ill-prepared for democracy.

The main methods teachers said they used to handle controversial political issues like

\footnotetext{
4 Overall the sample was almost exactly 50-50 male and female.

5 Not everyone gave an explanation, although invited to
} 
the Referendum were discussions, debates and group work, rather than didactic teaching. These should help children develop skills useful for electoral decisionmaking. For instance,

'We get kids to interact with each other and problems solve'

A few had made use of external speakers.

Several teachers stated that more needed to be done in schools to evoke or enhance student interest in political issues:

'It's difficult to engage with pupils about politics'.

'Children need more encouragement to engage with local and national politics'

A number of respondents were of the view that some or many young people had little interest in politics:

'They have a lack of interest in politics'

Politics is seen as boring

Political decisions are affecting young people and their disillusionment with the political process.

While some young people (like adults) are apolitical, these teachers were overgeneralising, since our own data and other surveys show many young people are interested in politics.

Teachers indicated what problems they faced in tackling political issues. The most common barrier was lack of time in the curriculum, mentioned by nearly two thirds of the sample. However, sizeable numbers also cited lack of suitable materials. The need to achieve balance and fears of being misreported for bias were also prominent factor that we shall return to. Several people who taught subjects like maths or PE stated that addressing political issues was not something they dealt with, as it was a matter for social subjects. This was seen partly as a matter of remit and partly of competence:

'Whilst I think teachers are able to find balance when discussing political and controversial issues, teachers often feel unqualified to discuss issues openly. The compartmentalisation of the curriculum creates a tendency for teachers to feel its not part of their subject especially when dealing with a sensitive contemporary issue.'

While the teaching of politics and debating political issues were not generally considered of the greatest importance, addressing the issues raised by the Referendum on independence at school were considered 'very important' by $87 \%$ of teachers. Only 2 thought it was 'not at all' the school's business.

Teachers recognised that the Referendum was both important and challenging, and it 
was thoroughly engaging the interest of most pupils. Among the epithets used were 'importance,' 'profound', 'momentous' and 'emotive subject'. It was noted that the outcome of the vote could 'change the direction of the country' or even 'permanently divide the country'.

In the main, only those teaching modern studies or other socially oriented subjects were able to describe how their school had approached preparation for the Referendum. Teachers of other disciplines mostly said they did not know what the school was doing to engage pupils with the issues of the referendum.

The majority of staff believed that handling the Referendum could have been done better if there had been better or more teaching materials available. Several indicated they would have liked training or templates so that coverage could have been of 'more interest to young people'.

About half of the teachers did not think the Referendum had posed extra challenges compared with other controversial subjects:

'I don't see why it could cause problems

'It should not be taught with any political slant of bias and should be an objective presentation of the facts and show a balance, a reasoned argument allowing the learner to make reasoned and balanced judgements and arguments of their own. The referendum or any political argument is merely a vehicle for teaching our young people to make up their minds, be aware of political bias and manipulations and be able to spot when political and any other argument is a distortion of the truth.

However a similar proportion did think there were particular problems evoked by the Referendum. Some referred to lack of time, lack of suitable materials, or the debate itself having too much uncertainty or 'too few facts'.

However, the greatest worry amongst teachers in our study reflected concerns amongst education authorities, and no doubt others, about the need to achieve neutrality.

\section{Views on balance and bias}

It has been a long standing tenet of pedagogy in general and political education in particular that teachers should avoid bias and expression of personal viewpoints on controversial matters in relation to politics. Proponents of the extension of political education in schools have emphasised that the intention is to improve skills in thinking and debating, along with understanding of political systems and procedures, but not to shape specific or party political attitudes (Crick and Lockyer 2010). Adopting a neutral stance not only avoids 'indoctrinating' young voters but provides a model for dispassionate analysis of evidence and arguments. During the lead up to the Referendum, guidance was issued to schools which reiterated in strong terms that schools and teachers should not seek to influence the views of children about the question of Independence versus continued Union in itself. 
In our questionnaire survey, many responses by young people emphasised that they wanted and expected balance when the Referendum was considered in school:

'Give us information from both sides of the argument'

'Give more details as to how it would affect us both positively and negatively'

'Offer more informative sessions during class about the issue/Pros \& cons'

'Have a debate showing about good and bad things about independence'

A few students took a different perspective. They also wanted school neutrality about the Referendum, but they indicated that more teaching on the subject might be experienced as an undesirable attempt to affect their opinions:

'The school should do nothing to influence us'

'I don't believe it is the school's position to influence me'.

It should be borne in mind that the issue at stake in the Referendum debate was especially momentous and recognised to be so. Some teachers acknowledged that they had strong views about Independence and it was desirable to heed official advice to be cautious. There was a risk of being overly 'influential' and extending the Referendum debate into school required 'careful handling'.

In our school-based discussions the two groups of modern studies teachers who gave us feed-back on the research findings reinforced the message that teachers felt constrained by management 'advice' to avoid giving grounds for accusations of bias. Some teachers at these events expressed a wish for more leeway and openness in the guidance they were given.

A number of young people voiced the view that it was naïve to think they would be influenced by their teachers on political matters. There was a widespread awareness amongst pupils that their teachers were or felt constrained during the lead up to Referendum. Most thought teachers should be able to give their honest views. It was said 'we are likely to know what they think anyway'.

This view comports with the results of surveys by Eichhorn (2014c) who concluded that many young people between 14-17 can make independent judgements about how to vote. There has been a long standing view reinforced by voting studies of the past that children are inclined to vote for the same political parties as their parents. This is decreasingly so. Eichhorn found that only half the young people interviewed said they would vote the same way as their parents.

\section{Concluding Discussion}

Within a relatively short period, the tide of opinion and practice in Scotland has moved towards the age of 16 as the new threshold for the right to vote. Before the 2014 Referendum, most adults were against reducing the minimum voting age from 18 , as with teachers in our study. Soon after, opinion had shifted to the point where a 
small majority were in favour (Curtice 2014). In the event, $89 \%$ of 16 and 17 year olds were registered to vote in the Referendum and three quarters actually did vote. This is a lower proportion than that for all voters, but higher than the rate for young adults aged 18-24 (Curtice 2014; House of Commons 2015). The Scottish Government decided to retain the lower voting age for the subsequent Scottish parliamentary election in 2016, so it now seems settled that 16-17 year olds in Scotland are entitled to exercise the rights and responsibilities of full democratic citizenship. This is not the case elsewhere in the UK, although the Westminster Government has accorded the Welsh Assembly the power to change the voting age in Wales (House of Commons 2015).

It is interesting to reflect on how this significant shift on one dimension of the childadult boundary fits with longer term trends on other dimensions. The lowest age at which young people can vote in Scotland is now aligned with the age at which they can marry, though they cannot obtain a full driving licence until 17 . The change means that for the first time large numbers of students at school can take part in elections. Before 1970 it was necessary to wait to the age of 21 to vote, while up to 1972 young people were able to leave school at 15 and move straight into work, as many did. Increased involvement in further and higher education since then means that engagement with the adult world of work has been deferred whereas the franchise has been extended in the opposite direction to younger people still at school. Achieving adult independence as regards finance and accommodation has happened later for many people in recent years. Also since the 1960s the average age at women have their first child has risen considerably. Whereas 50-60 years ago, women exercising their right to vote for the first time at $21+$ would soon bear a child or already have done so, on current trends a 16 year old voting may well wait 15 or even 20 years before becoming a parent. Thus it seems that legal changes mean young people have gained certain entitlements with accompanying responsibilities including the right to vote, but taking on other kinds of responsibility is now deferred as a result of changed social expectations and economic circumstances.

Those aged up to 18 remain covered by the UN Convention on the Rights of the Child and Scottish children's legislation. Cowden (2010) suggests that claims about different types of right need to be judged separately, but certain of young people's welfare and protective rights may be questioned if they are seen as competent to make adult decisions and engage in the adult political world, as Archard (2007) has suggested in the context of youth justice. If young people aged $16+$ are deemed mature enough to vote, they may be expected to take full responsibility for their behaviour, including criminal acts.

More specifically, there are major educational and political implications of the new minimum voting age both within Scotland and indirectly for the UK as a whole. Schools in Scotland are at the forefront of this change in the political status of young people. Hitherto schools have been able to regard those attending as future citizens, or citizens-in-the-making (Lockyer 2010), at best in the process of developing the capabilities to be politically active. Now for a large number of the school's senior population have the right to engage directly with national democratic decisions.

Both proponents and critics of the extension of the franchise, including many young people themselves, recognise that political competence is a critical requirement for 
16-17 year olds to exercise the newly acquired right to vote. Schools along with family and the media have a key role to play in enhancing understanding of political issues. The fact that the majority of students in our sample (four-fifths) believed that they were prepared at least to some extent to exercise the vote reflects some credit on what was achieved. On the other hand, many young people wanted more attention given in school to political issues.

Also important is motivation. Critics of a lower voting age have suggested that this would reduce electoral turnout (Mycock 2014), while proponents of change have indicated it might improve willingness to vote. Our and other evidence indicates that young people's interest in the Referendum was high. While a small minority of pupils were indifferent, larger numbers wanted more opportunities to learn about the issues. The Referendum may have been exceptional in having a single dominant issue, which tapped into strongly held beliefs and feelings about nationhood and identity.

Our findings overall are consistent with the conclusions of Eichorn study (2014b, c) that school discussions increased pupil engagement with politics and raised 'political confidence'. Feedback from the sample of pupils gathered to discuss the research (albeit a small and selective sample) was that the referendum debate had greatly encouraged interest in politics amongst fellow students, and many were dismayed by their lack of entitlement to vote in the subsequent general election. Adults' hitherto frequent assumption that young people typically lack interest in politics appears questionable, and increasingly outmoded.

The teaching of politics in school has historically been constrained by the fear that it may permit 'indoctrination' by teachers (Flew 2000) and this contributed to there being a culture in education in Britain antipathetic to engaging with controversial political issues in schools (Fraser 2003). Official 'guidance' from central and local government about covering the referendum urged circumspection and avoidance of bias. The findings from young people in our study showed that most wanted balance too. Moreover their feedback suggested that teachers were largely successful in avoiding bias. Many teachers in our survey acknowledged the need for balance too. On the other hand a number of teachers wanted the guidance to be clearer, while others regarded it as unnecessarily constraining, and even suggested that it showed a 'lack of trust' in teachers' professionalism. Some pupils thought too that the restriction on teachers from indicating their own views was unnecessary. The implication that students are likely to be unduly influenced by their teachers' opinions is another long-standing presumption that contemporary students may wish to challenge.

There are at least two other respects in which lowering the voting age might have consequences. The first is what will be the general impact both in school and in society beyond of 16-17 year olds becoming fully entitled political citizens. This could require adjustments be made not only to other formal age barriers, but more widely to shifting our conception of the threshold of adulthood and our thereby our attitudes to older teenagers. This may need to include revisiting the ability to influence how schools are run, as well as in other areas of participation in public life.

The second possible area of consequence is for the UK as a whole. The arrangement whereby the Scottish Parliament has a different age threshold for voting than the UK 
Parliament and Welsh and Northern Ireland assemblies seems difficult to justify, not least to young people in other parts of the UK. Equally it will make little sense to young Scots that they were entitled to vote in a Referendum on their remaining in the UK, but not entitled to share in the decision on whether the UK should belong to the European Union or to take part in UK national elections. While anomalies in political arrangements are not necessarily wrong or unstable, this discrepancy in the age threshold for voting seems a blatant and rectifiable injustice that will be hard to sustain.

\section{References}

Archard, D. (2007) 'Children's Rights and Juvenile Justice', in M. Hill, A. Lockyer and F. Stone (eds) Youth Justice and Child Protection, London: Jessica Kingsley.

Blackburn, R. (1993) The Electoral System in Britain,

British Youth Council (BYC) (2015) www.byc.uk/campaigns/votes-at-16aspx.

Chan, T. W. and Clayton, M. (2006) 'Should the voting age be lowered to 16 ?

Normative and empirical considerations', Political Studies, 54, 533-558.

Cowden, M. (2010) 'Capacity, claims and children's rights', Contemporary Political Theory, 11, 4, 362-380.

Crick, B. (1988) Education for Citizenship and the Teaching of Democracy in Schools, London: Qualifications and Curriculum Authority.

Crick, B. and Lockyer, A. (eds) Active Citizenship, Edinburgh: Edinburgh University Press.

Curtice, J. (2014) Blog.whatscotlandthinks.org/2014/12/many 16-17 year olds voted

Education Scotland (2013) Curriculum for Excellence : Political Literacy (CfE Briefing 14), Edinburgh http: //www.educationscotland.gov.uk/resources

Eichorn, J. (2014a) Results from the 2014 survey on 14-17 year old persons living in Scotland on the Scottish independence referendum, University of Edinburgh: AQMeN.

Eichorn, J. (2014b) 'Lessons learned: Trust 16-year old and schools with politics', Society Now, 20, 16-17.

Eichorn, J. (2014c) 'Newly enfranchised voters: Political attitudes of under 18-year olds in the context of the Referendum on Scotland's constitutional future', Scottish Affairs, 23, 3, 354-368.

Electoral Commission (2004) Age of Electoral Majority, London: Electoral Commission

Fahmy, E. (2006) Young Citizens, Aldershot: Ashgate. 
Fass, P. B. (2015) The Routledge History of Childhood in the Western World, London: Routledge.

Franklin, B. (1986) 'Children's Political Rights', in B. Franklin (ed) The Rights of Children, Oxford: Blackwell.

Furlong, A. and Cartmel, F. (2006) Young People and Social Change, Buckingham: Open University Press.

Furnham, A. and Gunter, B. (1989) The Anatomy of Adolescence, London: Routledge

Furnham, A. and Stacey, B. (1991) Young People's Understanding of Soceity,

London: Routledge.

Griffin, C. (2004) 'Representations of the young', in J. Roche, S. Tucker, R.

Thomson and R. Flynn (eds) Youth in Society, London: Sage.

Grover, S. G. (2011) Young People's Human Rights and the Policy of Voting Age, New York: Springer.

Hackett, C. (2004) 'Young people and political participation', in J. Roche, S. Tucker, R. Thomson and R. Flynn (eds) Youth in Society, London: Sage.

Harris, J. (1982) 'The Political Status of the Child', in K. Graham (ed) Contemporary Political Philosophy, Cambridge: Cambridge University Press.

Holt, J. (1971) Escape from Childhood, Harmondsworth, Penguin.

House of Commons (2015) Voting Age, Briefing Paper 1747, Westminster: House of Commons Library.

Irwin, S. (1995) Rights of Passage', London: UCL Press.

Jencks, C. (1996 ) Childhood, London: Routledge.

Lansdown, G. (2010), The realisation of children's participation rights' in B. PercySmith and N. Thomas (eds) A handbook of Children and Young People's Participation, London: Routledge.

Lehalle, H. (2006) 'Cognitive development in adolsecence', in S. Jackson and L. Goossens (eds.) Handbook of Adolsecent Development, New York: Psychology Press.

Liebel, M. (ed.) (2012) Children's Citizenship - Observed and Experienced, London: Palgrave.

Lindley, R (1989) 'Teenagers and Other Children', in G. Scarre (ed) Children, Parents and Politics, Cambridge: Cambridge University Press

Lister, R. (2003) Citizenship: Feminist Perspectives, (2 ${ }^{\text {nd }}$ edition), Basingstoke: 
Palgrave/Macmillan.

Lockyer, A. (2003) 'The Political Status of Children and Young People', in A. Lockyer, B. Crick \& J. Annette (eds), Education for Democratic Citizenship: Issues of Theory and Practice, Aldershot: Ashgate.

Lockyer, A. (2010) 'Young people as political citizen's in school', in B. Crick and A. Lockyer (eds) Active Citizenship, Edinburgh: Edinburgh University Press.

Munn, P. (2010) 'What can Active Citizenship Achieve for Schools and Through Schools, in B. Crick and A. Lockyer (eds) Active Citizenship, Edinburgh: Edinburgh University Press.

Mycock, A. (2014) 'The UK isn't ready to lower the voting age to 16, The Guardian, 14 October.

Percy-Smith, B. and Thomas, N. (eds.) (2010) A Handbook of Children and Young People's Participation, London: Routledge.

Purdy, L. (1992) In their Best Interests: The case against Equal Rights for Children, New York: Cornell University Press.

Qvortrup, J., Bardy, M. Sgritta, G. and Wintersberg, H. (eds) (1994) Childhood Matters, Aldershot: Avebury.

Qvortrup, J., Corsaro, W. and Honig, M-B. (eds) (2011) Childhood Studies, Basingstoke: Palgrave Macmillan.

Stewart, E. A., Wilson, I, Donnelly, P. D. and Greer, S. L. (2014) 'I didn't have a clue what we were doing': (not) engaging 16 and 17 year old voters in Scotland', Scottish Affairs, 23, 3, 354-368.

Tierney, S. (2014)'The Referendum on Scottish Independence: A process as swell as an event', Edinburgh Law Review, 18(2) 245-250.

Tisdall, E. K. M., Davis, J. M., Hill, M. and Prout, A. (eds) (2006) Children, Young People and Social Inclusion: Participation for What? Bristol: Policy Press.

Turkie, A. (2010) 'More than crumbs from the table: a critique of youth parliaments as models of representation for marginalised young people', in B. Percy-Smith and N. Thomas (eds) A handbook of Children and Young People's Participation, London: Routledge.

Wyness, M. (2013) Childhood and Society, Basingstoke: Palgrave Macmillan. 